тиви використання рослинної сировини Caltha palustris для більш детального фітохімічного та фармакологічного дослідження з метою подальшого створення косметичних, лікарських та лікувальнопрофілактичних засобів на ії основі.

\title{
Література:
}

1. Нестерук Ю. Рослинний світ Українських Карпат. Чорногора. Екологічні мандрівки - Львів, 2013. С. 122-123.

2. Гродзінський А.М. Лікарські рослини: Енциклопедичний довідник - Москва, 2009. С. 480-481.

3. Angkawijaya, P.L. Tran-Nguyen [et al] . Effect of extraction solvent on total phenol content, total flavonoid content, and antioxidant activity of Limnophila aromatica . Journal of Food and Drug Analysis. - 2014. № 22. P. 296-302.

4. Sumaiyah, Masfria and A. Dalimunthe. Determination of total phenolic content, total flavonoid content, and antimutagenic activity of ethanol extract nanoparticles of rhaphidophora pinnata (L.f) schott leaves. Rasayan Journal of Chemistry. - 2018. № (2). P. 505-510

5. Програма GUSAR : http://www.way2drug.com/gusar/

DOI https://doi.org/10.30525/978-9934-588-81-5-2.25

\section{ІННОВАЦІЇ ЯК СКЛАДОВА СВРОПЕЙСЬКИХ СТАНДАРТІВ ПРИ НАВЧАННІ ПРОВІЗОРІВ}

\author{
Маслак Г. С. \\ доктор біологічних наук, доцент, \\ завідувач кафедри біохімії та медичної хімії \\ Державний заклад "Дніпровська медична академія \\ Міністерства охорони здоров'я України» \\ Хмельникова Л. І. \\ кандидат хімічних наук, \\ дочент кафедри біохімії та медичної хімії \\ Державний заклад "Дніпровська медична академія \\ Міністерства охорони здоров'я Украӥни» \\ м. Дніпро, Україна
}

Впровадження інновацій в навчальний процес підвищує успішність, мотивацію студентів, стимулює компенсацію обмеженого простору аудиторії [1, с. 124]. 
На кафедрі біохімії та медичної хімії для студентів-провізорів викладається блок хімічних дисциплін, серед яких дві дисципліни (аналітична хімія та фізична і колоїдна хімія) входять до ліцензійного іспиту «Крок 1. Фармація». Як відомо до європейських стандартів освіти належать системний, контекстний, безперервний та компетентнісний підходи до якості освітянських процесів, що потребує облік усіх факторів, які впливають на навчальний процес.

3 метою забезпечення впровадження таких стандартів нами здійснюється методологічне і методичне обгрунтування і розробка організаційних технологічних підходів до методики викладання дисциплін. Для підготовки студентів - провізорів нами складено програми 3 дисциплін, базу тестових завдань для підготовки до ліцензійних іспитів «Крок-1» в системі «moodle», надруковано вісім навчально - методичних посібників. Для франкомовних студентів надруковано 3 навчально - методичних посібника для підготовки до «Крок 1 »на державній мові і готується видання цих посібників на французькій мові.

Вагомий внесок у якісну підготовку студентів - провізорів вносять сучасні комп'ютерні технології - сайт кафедри, на якому розташовані: інформація про порядок навчального процесу, плани, методичні розробки лекцій, практичних занять, самостійної роботи, теми для індивідуальної роботи, рекомендована література для самопідготовки, лекції в системі «Zoom» і багато іншого. Ця інформація полегшує підготовку студентів.

Студенти - провізори активно беруть участь у науковій роботі кафедри, представляючи свої наукові роботи на Всеукраїнських та міжнародних студентських конференціях. Так, за останні три роки виступили 13 іноземних студентів -провізорів зі доповідями своєї наукової діяльності.

Побудова педагогічного процесу на основі прозорості оцінювання студентів - провізорів формує довірливе ставлення студента до викладача, стимулює процес більш наполегливого отримання знань. Менші можливості мати під рукою необхідну літературу надає важливість самостійної підготовці студента. На допомогу йому - організація самостійної роботи студента за допомогою підручників, методичних видань, розроблених кафедрою за складними, важкими для освоєння тем, робота в бібліотеці з електронними ресурсами, підручниками та періодичними фармацевтичними виданнями.

Оснащення кафедри комп'ютерними класами, повсюдний доступ мережі «інтернет» полегшує контроль за самостійною роботою студента, сприяє різноманітності їі форм і підвищує ефективність, робить можливою підготовку студентів до ліцензійних іспитів «Крок-1». Слід зазначити, що робота 3 базою тестових завдань «Крок-1» $\epsilon$ 
обов'язковою, що сприяє концентрації уваги студентів на ключові закономірності хімічних дисциплін, дозволяє перевірити свої знання, адаптує до майбутнього ліцензуванню в країнах світу, де вони, можливо, будуть працювати.

Ми намагаємося робити все для того, щоб наші студенти в повному обсязі придбали знання і оволоділи навичками та уміннями, необхідними в їх майбутній професії. Лекційні лабораторії оснащені мультимедійними системами для демонстрації навчальних фільмів та презентацій. Лабораторні роботи оснащені відповідною апаратурою, хімічними реагентами і посудом. Позиція керівництва медичної академії полягає в тому, що якщо нам щось потрібно, то проблема вирішується в найкоротші терміни. Ставлення до студентів доброзичливе, але це не означає, що їм сходять з рук слабкі знання. Ми намагаємося донести інформацію до студентів так, щоб вони засвоїли іiі, а не отримали хорошу оцінку тому, що заплатили гроші за навчання.

Хімічна підготовка майбутніх провізорів $\epsilon$ основою формування основних трьох типів компетенцій (загальнокультурних, загально професійних і професійних), тому треба враховувати місце і роль кожної дисципліни в системі підготовки провізорів. Наприклад, при вивченні аналітичної хімії звертаємо увагу на те, що ця дисципліна $\epsilon$ «містком» довузівської і вузівської етапів хімічної освіти, закладає основи хімічної освіти майбутніх провізорів, бере участь у формуванні хімічних компетенцій як основи загальнокультурних і професійних компетенцій, тому за своєю суттю вони являються професійно орієнтованими. При вивченні фізичної і колоїдної хімії звертаємо увагу на виконання цією дисципліною функції універсальної, інтегративної мови, що дозволяє описувати і вивчати хімічні об'єкти, процеси, методи аналізу.

Високий професійний рівень сучасного фахівця - провізора передбачає володіння хімічними, фізико - хімічними методами аналізу i навичками щодо їх використання. У процесі оволодіння знаннями 3 аналітичної, фізичної та колоїдної хімії закладається теоретична i методологічна база для вивчення фармацевтичних дисциплін, що і складає основу фундаментальної підготовки провізора.

Придбання необхідних хімічних знань, умінь, навичок, що трансформуються в комплекс хімічних компетенцій, як основи майбутнього професіоналізму, створення передумов формування особистісних якостей, які диктуються потребами майбутньої професії - ось, що важливо для підготовки студентів - провізорів до їх подальшої навчальної та професійної діяльності.

Як показали опитування студентів про причини їх неуспішності по деяким хімічним дисциплінам, поряд з об'єктивними труднощами їх засвоєння величезний вплив відіграє те, що студент часто погано уяв- 
ляє собі місце і роль вивчаємих дисциплін у майбутній професійній діяльності.

Методичне забезпечення дисципліни для студентів - провізорів розроблено на основі компетентнісного підходу, модульності і послідовності викладання навчального матеріалу, що включає робочу програму, дидактичні та контролюючі матеріали і характеризується повнотою і доступністю інформації. Такий підхід сприяє вирішенню протиріччя між обсягом навчального матеріалу і навчальним часом на його вивчення і визначає для студентів - провізорів кінцеві цілі освоєння хімічних дисциплін у вигляді хімічних компетенцій і напрямки їх досягнення (види, способи діяльності, в тому числі самостійної).

У методичних матеріалах до виконання лабораторних робіт значна увага приділяється профілізації викладання в плані ознайомлення студентів 3 фармакопейними методиками аналізу різних лікарських речовин. Кожна лабораторна робота виконується як індивідуальне навчально - дослідне завдання, що дозволяє найбільш об'єктивно оцінювати практичні навички студента - провізора. Методичні рекомендації щодо організації самостійної роботи спрямовані на закріплення вміння пошуку, накопичення та обробки наукової інформації.

Перед викладацьким складом кафедри ставиться завдання навчити іноземних студентів практичному володінню хімічною термінологією державною мовою для спілкування як у медичній навчальнопрофесійній сфері, так і в побутовому середовищі. Звідси випливає, що в процесі викладання хімічних дисциплін необхідно враховувати як систему української мови, так і основні положення методики викладання української мови як іноземної.

Успішність навчання в значній мірі залежить від узгодженості роботи викладачів хімічних дисциплін по здійсненню єдиного мовного режиму. Під цим розуміємо єдину систему вимог до діяльності викладачів з обліку рівня володіння студентами українською мовою 3 хімічних дисциплін.

Особливість навчального процесу для іноземних студентів полягає в тому, що мова виступає в якості мети, предмета, змісту і засобу навчання; дидактична стратегія навчання формується насамперед на комунікативній і прагматичній функціях мови. Українська мова вивчається як спеціальний предмет на заняттях з української мови, на заняттях 3 хімічних і інших загальноосвітніх дисциплін, слугуючи засобом їх навчання.

Навчання хімічній лексиці і створення умов її активізації в процесі навчального спілкування - найважливіше завдання, що стоїть перед усіма викладачами. Вирішення цього завдання можливе лише за умови оптимізації навчального процесу в цілому і пов'язану з цим розробку методів і прийомів навчання. 
В даний час використовуємо головним чином комунікативно - діяльний метод навчання, який передбачає комунікативно - мотиваційну поведінку викладача і студентів в ході заняття, а також предметність процесу комунікації, яка виражається в ретельному відборі мовних зворотів, тем, ситуацій спілкування, що відображають практичні інтереси і потреби студентів - іноземців.

Важливою частиною навчання студентів - іноземців $\epsilon$ придбання навичок і умінь, так як для досягнення комунікативної мети необхідно їх сформувати в основних видах мовної діяльності: аудіювання, говоріння, читання і письма.

Серед шляхів підвищення ефективності навчального процесу розглядаємо координацію навчання мови і хімічними, а також загальноосвітними дисциплінами. Наукову основу координації повинні складати дослідження мови науки, знання якісних і кількісних характеристик мовних одиниць в науковому стилі, особливостей усної наукової мови, структурної організації наукових текстів тощо.

Для сприйняття і розуміння наукових термінів і фізико - хімічних явищ поряд з аудиторними заняттями, на яких студенти - іноземці разом з викладачем озвучують і письмово складають словник фізико хімічних термінів, велику увагу приділяємо самостійній роботі.

На підставі вищесказаного можна ще раз підкреслити, що на заняттях 3 хімічних дисциплін виконуємо наступне: дотримуємося вимог педагогіки і методики викладання сучасної української мови; враховуємо знання української мови на кожному етапі навчання; використовуємо ті форми організації заняття, ті прийоми введення, закріплення і контролю навчального матеріалу, які відповідають рівню сформованості у студентів - іноземців навичок і умінь в певних видах мовної діяльності; дотримуваємося поетапного обсягу пропонованої інформації текстового матеріалу.

Для ефективного навчання хімічної мови використовуємо взаємовідвідування занять викладачами, спільне створення навчальнометодичних матеріалів (навчальних тестів, методичних вказівок i посібників), проведення конкурсів серед студентів, відвідування іноземними студентами медичного музею, участь в міжнародних студентських конференціях тощо.

Завдяки цьому навчальні матеріали хімічних дисциплін виступають не тільки як предмет пізнання, але і в ролі активного апарату спеціалізованого вивчення мови. У зв'язку з цим активно здійснюємо міждисциплінарні зв'язки не лише між українською мовою і кожною хімічною дисципліною, а й взаємних зв'язків останніх.

Таким чином, підвищення якості підготовки фахівця неможливо без взаємозв'язку хімічних і фармацевтичних дисциплін, їх інтеграції в процесі навчально-пізнавальної та науково-дослідницької діяльності 
студентів, важливих для формування їх наукового світогляду і хімікофармацевтичної культури.

\title{
Література:
}

1. Березюк О.С. Шляхи модернізації освітньої системи України / О.С. Березюк, В.І. Смоляр, О.М. Власенко. Тенденції модернізації національних освітніх систем: збірник наукових праць/за ред. О.С. Березюк. Житомир : Вид-во ЖДУ ім. І. Франка, 2014. 158 с.

DOI https://doi.org/10.30525/978-9934-588-81-5-2.26

\section{РЕЛЕВАНТНІСТЬ ЗАСТОСУВАННЯ КОМПЛЕКСНИХ ГОМЕОПАТИЧНИХ ПРЕПАРАТІВ ЯК АЛЬТЕРНАТИВНОГО МЕТОДУ ТЕРАПІЇ СИНДРОМУ ХРОНІЧНОЇ ВТОМИ}

\author{
Неляпіна М. М. \\ студентка V курсу кафедри загальної практики-сімейної медицини \\ медичного факультету \\ Харківський наиіональний університет імені В. Н. Каразіна \\ Гайдукова О. О. \\ кандидат фармачевтичних наук, \\ асистент кафедри загальної практики-сімейної медицини \\ Харківський національний університет імені В. Н. Каразіна
}

Мінаєва А. О.

кандидат біологічних наук, асистент кафедри загальної практики-сімейної медицини Харківський національний університет імені В. Н. Каразіна

\section{Салун О. О.}

асистент кафедри загальної практики-сімейної медицини Харківський національний університет імені В. Н. Каразіна

Павлова О. Л.

асистент кафедри загальної практики-сімейної медицини Харківський національний університет імені В. Н. Каразіна м. Харків, Україна

Діаметральні наукові суперечності вітчизняних та зарубіжних терапевтичних шкіл щодо диференціації синдрому хронічної втоми (CXВ) як окремої нозологічної одиниці, зумовлюють сучасні тенденції до його різнобічного дослідження. Надзвичайна поліморфність симптоматичних проявів цієї патології, її клінічна «мімікрія» інших 